\title{
Forested Wetland Hydrology in a Large Mississippi River Tributary System
}

\author{
Jacob F. Berkowitz ${ }^{1}$ (D) David R. Johnson ${ }^{2} \cdot$ Jaybus J. Price $^{1}$
}

Received: 2 June 2019 / Accepted: 13 November 2019 / Published online: 14 December 2019

(C) The Author(s) 2019

\begin{abstract}
Wetlands in the Mississippi River Valley provide numerous functions supported by prolonged periods of soil saturation or inundation. However, few studies document forested wetland hydropatterns, especially in altered systems. In this study, we evaluated hydrologic drivers of forested wetlands in the Yazoo Basin, a large Mississippi River tributary system exhibiting regional hydrologic alteration. Results from 56 water table monitoring locations indicate that precipitation induced the majority (76\%) of wetland saturation events, defined as soil inundation or water tables within $\leq 30 \mathrm{~cm}$ of the surface for $\geq 14$ consecutive days. Flooding triggered $19 \%$ of saturation events, and $5 \%$ of events occurred in response to precipitation induced high water tables followed by flood inundation. Data suggest that most wetlands examined (87\%) would persist in the absence of flooding, and that duration and inundation patterns differed with dominant water source. A multi-year hydropattern analysis highlights the influence of precipitation derived saturation during low evapotranspiration winter periods, spring flood water contributions in some wetlands, and decreasing water tables throughout summer and fall. A discussion of rainfall normality and stream discharge places the dataset in a larger context. Results reflect changes in historic hydropatterns, informing efforts to maximize wetland functions during forested wetland management and restoration.
\end{abstract}

Keywords Wetland hydrology $\cdot$ Flood control $\cdot$ Hydropatterns $\cdot$ Forested wetland $\cdot$ Yazoo Basin $\cdot$ Mississippi River

\section{Introduction}

Forested wetlands within the Mississippi River alluvial valley provide a variety of wetland functions including maintenance of faunal and floral habitats, detention and storage of precipitation and floodwater, and biogeochemical cycling of nutrients (Smith and Klimas 2002). These functions result in flood risk reduction, water quality improvements, and recreational opportunities that benefit society. Historically, more than 10 million ha of forested wetlands extended from the mouth of the Ohio River to the Gulf of Mexico (King et al. 2006).

Electronic supplementary material The online version of this article (https://doi.org/10.1007/s13157-019-01249-5) contains supplementary material, which is available to authorized users.

Jacob F. Berkowitz

Jacob.F.Berkowitz@usace.army.mil

1 U.S. Army Corps of Engineers, Engineer Research and Development Center, Vicksburg, MS, USA

2 U.S. Army Corps of Engineers, Vicksburg District, Vicksburg, MS, USA
Landscape alterations decreased the forested wetland extent by $75 \%$, largely through conversion of forested wetland habitats to agricultural lands and the implementation of extensive flood control projects (The Nature Conservancy 1992).

Many studies in the region investigate the capacity of the remaining forested wetlands to provide diverse habitats, forest products, and improve water quality (Kellison and Young 1997; Fredrickson et al. 2005). However, relatively few studies examine the hydrologic drivers supporting forested wetlands compared with the number of publications evaluating waterfowl, vegetation, and other topics (Fredrickson and Heitmeyer 1988; Wigley and Roberts 1994). Water source and pattern ultimately determine the form and function of all wetlands (Gosselink and Turner 1978), and understanding forested wetland hydrology is especially important given the magnitude of the decline in forested wetland extent in the region (Fredrickson 2005). Hydrology also interacts with other factors (i.e., vegetation and soils), to regulate ecological productivity, organic matter accumulation, and floodwater attenuation; making it a key component to consider during conservation and restoration efforts (Berkowitz and White 2013). 
Mitsch and Gosselink (2015) outline typical hydropatterns in alluvial swamps and hardwood wetland forests, which experience elevated water table levels and surface inundation in response to precipitation during winter when evapotranspiration is low (Fig. 1). Spring flooding provides hydrologic supplements in some systems, and water levels decrease as the growing season progresses, evapotranspiration accelerates, and precipitation declines. This classic view of forested wetland hydropattern is well established, but may not reflect current conditions since much of the Mississippi River Valley has been altered by the construction of levees, drainage works, stream channelization and dredging (Theiling and Nestler 2010). These alterations include the development of over $5900 \mathrm{~km}$ of levees in addition to operation of dams and flood control structures designed to manage river stages for navigation and/or to prevent flooding.

The modification of the Mississippi River and tributary systems induced more erratic flow regimes, more frequent major floods, and fewer years with stable water levels essential for moist-soil plants and aquatic vegetation growing in floodplains and backwater areas (Sparks et al. 1998). Current conditions result in higher river stages within the constrained river floodplain and decreased direct connectivity between forested wetlands and lotic systems compared with historical data (i.e., less overbank flooding; Belt 1975; Opperman et al. 2010). As a result, many forested wetlands are now subject to a combination of direct precipitation and backwater flooding as the major sources of hydrology (Smith
Fig. 1 Theoretical hydropatterns for an alluvial swamp forest (upper panel) and hardwood wetland forest (middle panel; adapted from Mitsch and Gosselink 2015). Note that the water table increases in response to winter precipitation, with supplemental spring flood effects occurring in some areas. Water tables decrease during summer and fall in response to lower precipitation and increased evapotranspiration. The water balance (lower panel; adapted from data available in Matsuura et al. 2009) within the study area corresponds to the theoretical water table fluctuations in the upper panels, with water surpluses occurring during the winter months coinciding with the water table increases. The subsequent declines in precipitation and accelerating evapotranspiration during summer lead to soil moisture loss and moisture deficits, resulting in lower water tables. Cooler temperatures and increasing precipitation then recharge the system, with soil moisture gains occurring later in the year

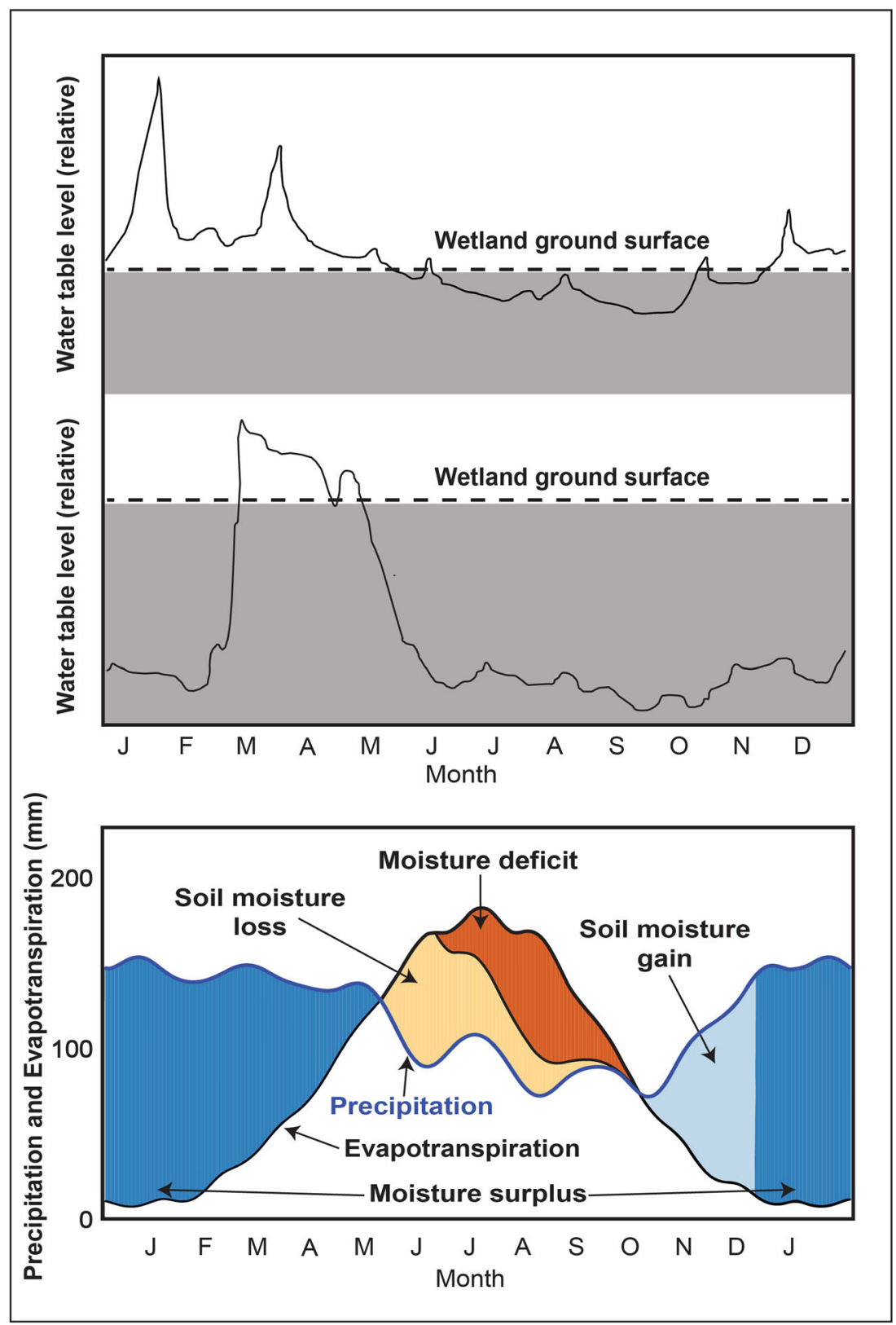


and Klimas 2002). Backwater flooding describes inundation resulting from impeded drainage, when the flood stage in higher-order waterways inhibits drainage within adjacent tributaries. Impeded drainage leads to increasing water tables and surface inundation. Additional flooding results from water accumulating behind levees and other flood control structures. For example, over 200,000 ha of land was flooded in the Yazoo Basin, a major Mississippi River tributary system, during 2019 for a period exceeding 120 days. The flooding was induced by extremely high (over $200 \%$ above average) precipitation coupled with high river levels in the Mississippi River which precluded downstream drainage and necessitated closure of multiple water control structures (NOAA 2019).

Land use and management also influences forested wetland hydrology. For example, Kolka et al. (2000) reported significant differences between restored and natural forested wetlands, including changes of natural patterns of evapotranspiration and throughfall that impacted water table levels. That study highlighted the need for additional research characterizing forested wetland hydrology, especially in altered systems. Richardson and McCarthy (1994) identified increases in runoff and decreases in evapotranspiration following conversion of forested wetlands to other land uses. Hunter et al. (2008) investigated the effect of altered hydrology on water quality improvement, suggesting that hydropattern and connectivity be incorporated into forested wetland restoration design. Walton et al. (1996) linked forest surface inundation with river stages on the Cache River in Arkansas reporting that overbank and backwater flooding provide the major water sources in the reach examined. The authors of that study further emphasized the need for additional research on water sources and hydropatterns in forested wetlands and more work investigating the impact of alteration on forested wetland hydrology.

In response to the need for additional research, we evaluated hydrologic drivers in forested wetlands within the Yazoo Basin, a major tributary to the Mississippi River that has undergone extensive hydrologic alteration. Objectives included: 1) identify dominant wetland water sources (i.e., precipitation, flooding, or combination) during 95 wetland saturation events occurring at 56 monitoring locations, 2) place results in a larger context via analyses of precipitation and stream flow normality, and 3) evaluate multiyear forested wetlands hydropatterns in the region. We also discuss implications for forested wetland restoration and management.

\section{Methods}

\section{Study Area}

The study occurred in the Yazoo Basin, a 20,000 km² tributary of the Mississippi River. The basin has an average southward slope of $11.3 \mathrm{~cm} / \mathrm{km}$ beginning at Memphis, TN and continuing southward to Vicksburg, MS (USA). (Saucier 1994). The basin represents the largest major sub-basin of the Mississippi River alluvial valley, occupying portions of the Mississippi River alluvial plain section of the coastal plain physiographic province (USDA-NRCS 2006). Climate is humid subtropical, with temperate winters (January mean of $5.5^{\circ} \mathrm{C}$ ) and long hot summers exhibiting average maximum temperature of $32.2{ }^{\circ} \mathrm{C}$ (Southern Regional Climate Center 1998). Longterm average total precipitation measures $129 \mathrm{~cm}$ per year, with $12 \mathrm{~cm}$ per month occurring from December to April decreasing to $8 \mathrm{~cm}$ per month in August, September, and October. The precipitation pattern in conjunction with evapotranspiration rates results in excess moisture during winter and spring, followed by soil moisture losses and moisture deficits from May to October (Fig. 1; Brown et al. 1971).

\section{Ground Water Monitoring and Analyses}

Ground water monitoring well installation occurred at 56 forested wetland study sites throughout the Yazoo Basin (Fig. 2). Wells consisted of slotted PVC pipes instrumented with pressure transducers (Insitu LevelTroll 500® or Ott OTT Orpheus Mini( $\left.{ }^{\circledR}\right)$ at or below $50 \mathrm{~cm}$ of the soil surface according to guidance provided in USACE (2005). Water table measurements were automatically recorded at a minimum interval of $12 \mathrm{~h}$ from November 2010 until October 2011. All monitoring locations were distributed based upon access to public lands, mapped flood frequency and duration (where available), and site condition to include analyses of mature second growth forest and reforested farmed wetlands (Table 1). Mature second growth forests were at least 60 years old and experienced natural regeneration following historic logging. Restored forested wetlands areas consisted of afforested poorly drained, agricultural lands that historically supported forested wetlands. All restored sites were less than 25 years old during the study (Berkowitz 2019). Prior to restoration, study locations were managed for row crop production including corn, soybeans, cotton, and rice varieties.

Each study area exhibited field indicators of hydrophytic vegetation, hydric soils, and wetland hydrology as outlined in USACE (2010), confirming the presence of wetlands. A mixture of Fraxinus pennsylvanica, Quercus texana, Quercus lyrata, Carya aquatica, and other flood-tolerant hydrophytes dominated both restored and naturally regenerated locations (Berkowitz 2019). Soils throughout the study area include Sharkey clay (Very-fine, smectitic, thermic Chromic Epiaquerts), Alligator clay (Very-fine, smectitic, thermic Chromic Dystraquerts), Forestdale silty clay loam (Fine, smectitic, thermic Typic Endoaqualfs) and related series (Soil Survey Staff 2019). The rate of water table recession was calculated from water table monitoring data by evaluating the change in water table depths following precipitation events 
Fig. 2 Forested wetland study locations within the Yazoo Basin, Mississippi, USA. Numerical location designations correspond to the water table monitoring data provided in Table 1

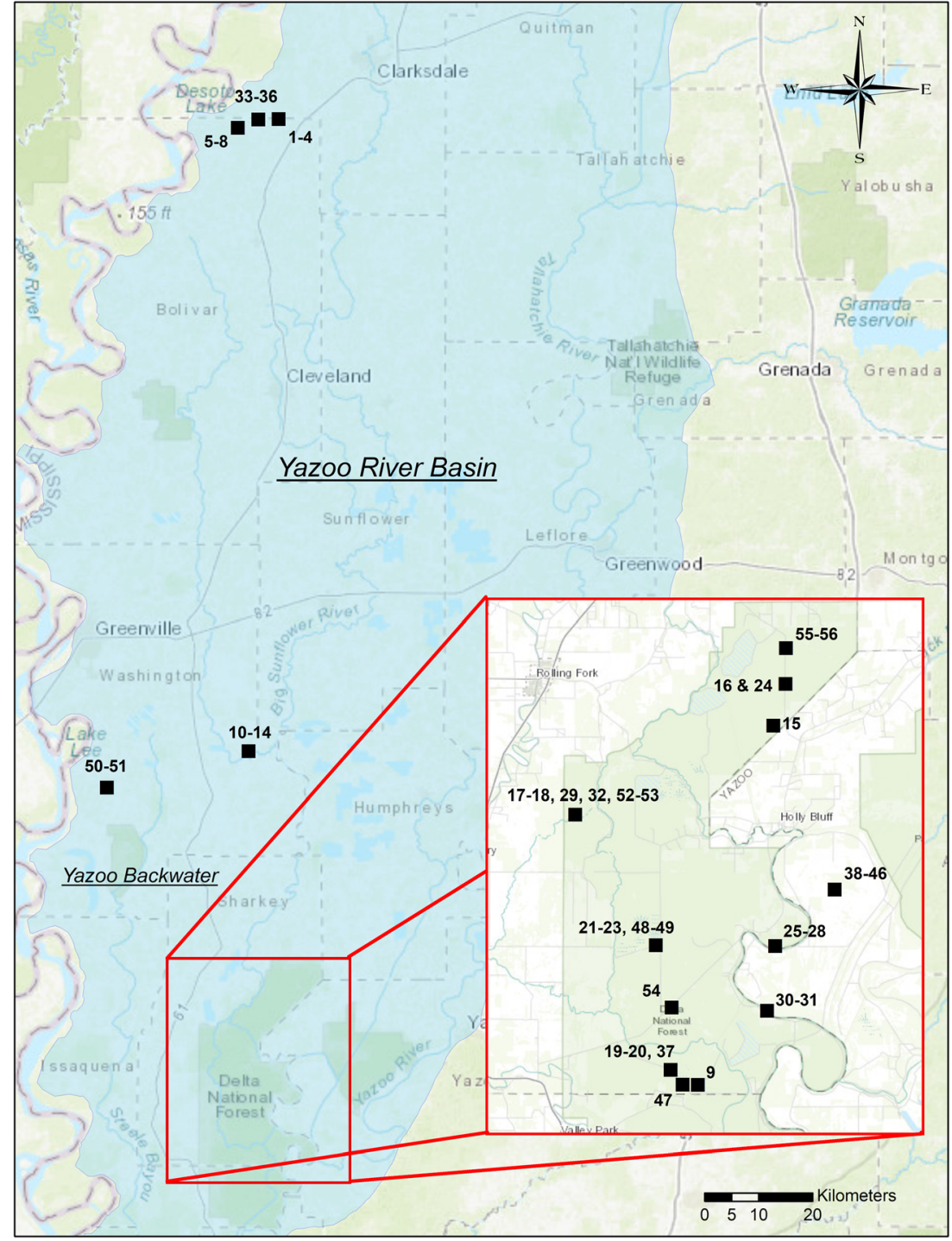

when no additional precipitation events occurred for at least four days. The change in water table depth was divided by the number of days required for water tables to return to baseline conditions. This yielded recession rates ranging from 0.03 to $0.44 \mathrm{~m} /$ day (average $0.20 \mathrm{~m} /$ day). Field indicators of hydric soils were present at all study locations, including the commonly observed indicators Depleted Matrix, Depleted Below Dark Surface, and Redox Depressions (USDA-NRCS 2018). Field indicators of wetland hydrology were present at all study sites, including the following which were commonly observed: Surface Water, High Water Table, Saturation, Sediment Deposits, Drift Deposits, Water Marks, Algal Mat or Crust, Water Stained Leaves, Oxidized Rhizospheres Along Living Roots, Surface Soil Cracks, Sparsely Vegetated Concave Surface, Drainage Patterns, Moss Trim Lines, Geomorphic Position, the FAC Neutral Test, and Crawfish Burrows (USACE 2010).
Analyses of water table monitoring data applied the Technical Standard for Monitoring of Potential Wetland Sites (USACE 2005), which defines the minimum criteria of wetland hydrology as inundation or soil saturation within $\leq 30 \mathrm{~cm}$ of the soil surface for $\geq 14$ consecutive days during the growing season at a minimum frequency of 5 years in 10 (i.e., $\geq 50 \%$ probability). Growing season dates utilized the standard defined in USACE (2010), encompassing periods when active plant growth is observed (e.g., bud burst) or when soil temperatures remain above $5^{\circ} \mathrm{C}$. This wetland hydrology threshold was selected because it has been utilized in multiple wetland identification studies (Berkowitz and Sallee 2011; Berkowitz et al. 2014, 2017) and adheres to recommendations from National Research Council (1995) ensuring that water persists within the major rooting zone of plants long enough to impact vegetation distribution and hydric soil oxidationreduction potentials (e.g., anaerobic conditions). The standard 
Table 1 Wetland hydrology monitoring location information from the 2010-2011 period including mapped flood duration and frequency (N/A denotes no data available), elevation, condition $(\mathrm{RE}=$ restored; $\mathrm{SG}=\mathrm{sec}-$ ond growth), number of saturated days (i.e., soil saturation or inundation within $\leq 30 \mathrm{~cm}$ of the surface), number of saturation events (periods with $>14$ consecutive days of saturation or inundation within $\leq 30 \mathrm{~cm}$ of the soil surface), and water source $(\mathrm{R}=$ rainfall; $\mathrm{F}=$ flooding; $\mathrm{RSF}=$ rainfall followed by supplemental flooding) associated with each saturation event

\begin{tabular}{|c|c|c|c|c|c|c|c|}
\hline Study location & Duration (days) & Frequency (years) & Elevation (m) & Condition & Saturated days & Wetland saturation events & Water source \\
\hline 1 & N/A & N/A & 44.7 & $\mathrm{RE}$ & 49 & 2 & $\mathrm{R}, \mathrm{R}$ \\
\hline 2 & N/A & N/A & 47.8 & $\mathrm{RE}$ & 68 & 1 & $\mathrm{R}$ \\
\hline 3 & N/A & N/A & 47.8 & $\mathrm{RE}$ & 61 & 2 & $\mathrm{R}, \mathrm{R}$ \\
\hline 4 & N/A & $\mathrm{N} / \mathrm{A}$ & 42.6 & $\mathrm{RE}$ & 42 & 2 & $\mathrm{R}, \mathrm{F}$ \\
\hline 5 & N/A & N/A & 46.8 & $\mathrm{RE}$ & 144 & 3 & $\mathrm{R}, \mathrm{R}, \mathrm{R}$ \\
\hline 6 & N/A & N/A & 46.6 & $\mathrm{RE}$ & 132 & 2 & $\mathrm{R}, \mathrm{R}$ \\
\hline 7 & N/A & N/A & 46.0 & $\mathrm{RE}$ & 121 & 2 & $\mathrm{R}, \mathrm{R}$ \\
\hline 8 & N/A & N/A & 46.9 & $\mathrm{RE}$ & 143 & 2 & $\mathrm{R}, \mathrm{R}$ \\
\hline 9 & 7 & 1.5 & 26.2 & SG & 57 & 1 & $\mathrm{~F}$ \\
\hline 10 & N/A & N/A & 31.9 & $\mathrm{RE}$ & 114 & 1 & $\mathrm{R}$ \\
\hline 11 & N/A & N/A & 32.0 & $\mathrm{RE}$ & 111 & 2 & $\mathrm{R}, \mathrm{R}$ \\
\hline 12 & N/A & N/A & 31.9 & $\mathrm{RE}$ & 129 & 2 & $\mathrm{R}$ \\
\hline 13 & N/A & N/A & 31.3 & $\mathrm{RE}$ & 109 & 1 & $\mathrm{R}, \mathrm{R}$ \\
\hline 14 & N/A & N/A & 31.9 & $\mathrm{RE}$ & 120 & 2 & $\mathrm{~F}$ \\
\hline 15 & $<7$ & 5 & 29.1 & SG & 125 & 2 & $\mathrm{R}, \mathrm{F}$ \\
\hline 16 & $<7$ & 5 & 28.4 & SG & 54 & 1 & $\mathrm{R}$ \\
\hline 17 & $<7$ & 2 & 28.1 & SG & 124 & 2 & $\mathrm{R}, \mathrm{R}$ \\
\hline 18 & 7 & 1.5 & 27.7 & SG & 129 & 1 & $\mathrm{R}$ \\
\hline 19 & 7 & 1.5 & 26.9 & SG & 152 & 3 & $\mathrm{R}, \mathrm{R}, \mathrm{F}$ \\
\hline 20 & 7 & 1.5 & 26.9 & SG & 152 & 3 & $\mathrm{R}, \mathrm{R}, \mathrm{F}$ \\
\hline 21 & 7 & 1.5 & 26.7 & SG & 114 & 3 & $\mathrm{R}, \mathrm{R}, \mathrm{F}$ \\
\hline 22 & 7 & 1.5 & 26.9 & SG & 181 & 3 & $\mathrm{R}, \mathrm{R}, \mathrm{F}$ \\
\hline 23 & 7 & 1.5 & 26.8 & SG & 114 & 3 & $\mathrm{R}, \mathrm{R}, \mathrm{F}$ \\
\hline 24 & $<7$ & 5 & 28.5 & SG & 56 & 1 & $\mathrm{R}$ \\
\hline 25 & $<7$ & 10 & 28.5 & $\mathrm{RE}$ & 29 & 1 & $\mathrm{~F}$ \\
\hline 26 & 14 & 1.11 & 26.6 & $\mathrm{RE}$ & 109 & 2 & $\mathrm{R}, \mathrm{F}$ \\
\hline 27 & $<7$ & 5 & 27.8 & $\mathrm{RE}$ & 98 & 3 & $\mathrm{R}, \mathrm{R}, \mathrm{F}$ \\
\hline 28 & 7 & 1.25 & 27.0 & $\mathrm{RE}$ & 31 & 1 & $\mathrm{~F}$ \\
\hline 29 & $<7$ & 1.5 & 27.9 & SG & 129 & 2 & $\mathrm{R}, \mathrm{R}$ \\
\hline 30 & $<7$ & 5 & 28.2 & $\mathrm{RE}$ & 43 & 1 & $\mathrm{~F}$ \\
\hline 31 & 7 & 1.5 & 27.3 & $\mathrm{RE}$ & 32 & 1 & $\mathrm{~F}$ \\
\hline 32 & 7 & 1.5 & 27.7 & SG & 134 & 1 & $\mathrm{R}$ \\
\hline 33 & N/A & N/A & 44.9 & $\mathrm{RE}$ & 57 & 2 & $\mathrm{R}, \mathrm{R}$ \\
\hline 34 & N/A & N/A & 46.1 & $\mathrm{RE}$ & 49 & 1 & $\mathrm{R}$ \\
\hline 35 & N/A & N/A & 46.9 & $\mathrm{RE}$ & 67 & 2 & $\mathrm{R}, \mathrm{R}$ \\
\hline 36 & N/A & N/A & 46.4 & $\mathrm{RE}$ & 61 & 2 & $\mathrm{R}, \mathrm{R}$ \\
\hline 37 & 7 & 1.5 & 26.9 & SG & 100 & 2 & $\mathrm{R}, \mathrm{R}$ \\
\hline 38 & 28 & 1.25 & 25.8 & $\mathrm{RE}$ & 157 & 1 & RSF \\
\hline 39 & 7 & 1.5 & 27.4 & $\mathrm{RE}$ & 111 & 1 & $\mathrm{R}$ \\
\hline 40 & 28 & 1.25 & 25.6 & $\mathrm{RE}$ & 165 & 1 & $\mathrm{R}$ \\
\hline 41 & 28 & 1.25 & 25.6 & $\mathrm{RE}$ & 153 & 1 & RSF \\
\hline 42 & 21 & 1.25 & 26.6 & $\mathrm{RE}$ & 120 & 1 & $\mathrm{R}$ \\
\hline 43 & 28 & 1.25 & 26.2 & $\mathrm{RE}$ & 157 & 2 & $\mathrm{R}, \mathrm{F}$ \\
\hline 44 & 28 & 1.25 & 25.9 & $\mathrm{RE}$ & 169 & 1 & RSF \\
\hline 45 & 28 & 1.25 & 25.8 & $\mathrm{RE}$ & 160 & 1 & RSF \\
\hline 46 & 7 & 1.5 & 26.7 & $\mathrm{RE}$ & 122 & 1 & $\mathrm{R}$ \\
\hline
\end{tabular}


Table 1 (continued)

\begin{tabular}{llllllll}
\hline Study location & Duration (days) & Frequency (years) & Elevation $(\mathrm{m})$ & Condition & Saturated days & Wetland saturation events & Water source \\
\hline 47 & 7 & 1.5 & 26.9 & SG & 46 & 1 & F \\
48 & 7 & 1.5 & 26.6 & SG & 133 & 1 & RSF \\
49 & 7 & 1.5 & 26.8 & SG & 117 & 3 & R, R, F \\
50 & N/A & N/A & 31.4 & RE & 74 & 2 & R, R \\
51 & N/A & N/A & 31.5 & RE & 57 & 1 & R \\
52 & $<7$ & 1.5 & 27.9 & SG & 72 & 2 & R, R \\
53 & 7 & 1.5 & 27.5 & SG & 132 & 2 & R, R \\
54 & $<7$ & 2 & 27.4 & SG & 56 & 1 & F \\
55 & $<7$ & 10 & 29.7 & SG & 109 & 2 & R, R \\
56 & $<7$ & 5 & 29.5 & SG & 83 & 2 & R, R \\
\hline
\end{tabular}

is also applied by regulatory agencies responsible for implementing wetland provisions within the Clean Water Act and the National Food Security Act (USACE 2010).

Data from each of the 56 study sites monitored during the 2010-2011 period was evaluated to determine the number of wetland saturation events (i.e., periods where soil inundation or water tables remained within $\leq 30 \mathrm{~cm}$ of the soil surface for $\geq 14$ consecutive days). Each wetland saturation event was then classified as being derived from 1) precipitation, 2) flooding, 3) a combination of precipitation induced high water tables followed by floodwater inputs, or 4) precipitation induced saturation followed by a low water table period and separate precipitation or flood event(s) occurring later in the season (Fig. 3). Previous studies have utilized a similar approach to evaluate wetland water sources; including Davis et al. (1996) who identified the relative contribution of precipitation, groundwater and runoff to wetland hydropattern in northern Florida by examining hydrograph responses to rainfall, groundwater discharge, and other factors.

The classification analyses evaluated water table responses to precipitation and changes in river hydrograph (i.e., stage). Precipitation-driven wetland saturation events display linkages between individual rainfall events and water table levels as indicated by a high temporal variability and rapidly fluctuating groundwater levels (Fig. 3a). Conversely, events associated with flood events generally produced smooth water table hydrographs that mimic the shape of river stage fluctuations even if the timing of flood effects are muted or occur following a time lag (Fig. 3b). Wetland saturation events resulting from a combination of sources were characterized by initial high water tables in response to precipitation for a minimum duration of 14 consecutive days followed by subsequent flood effects that enhanced water table height or prolonged the wetland hydroperiod (Fig. 3c). Some study locations exhibited multiple saturation events separated by low water periods (Fig. 3d).
Statistical analyses utilized one-way analysis of variance (ANOVA) following testing for normality (Shapiro-Wilk test) and homoscedasticity (Levene's test). Pairwise comparisons used the Tukey HSD test. The ANOVA approach compared the duration of wetland hydrology at study locations (dependent variable) between hydrologic sources (independent variable; e.g., precipitation-driven vs. flood-driven) and study location condition (i.e., mature second growth vs. restored locations). When the assumptions for ANOVA were violated, the non-parametric Kruskal-Wallis test with DunnBonferroni pairwise comparisons was applied (designated as $\mathrm{P}^{\prime}$ in the text). The non-parametric tests compared the duration of wetland hydrology during individual saturation events (dependent variable) between hydrologic sources (independent variable; e.g., precipitation vs. flooding); compared the duration and maximum height of surface inundation events (dependent variables) between hydrologic sources (independent variable; e.g., precipitation vs. flooding); and compared the observed duration of wetland saturation (dependent variable) against the mapped flood duration zones (independent variable). Each saturation event and study location was considered an independent measurement for the analysis. All significance was evaluated at $\alpha=0.05$, using SPSS version 25 (IBM, Inc.).

\section{Climate Analyses}

Water table measurements were placed into a larger context by evaluating patterns of rainfall and streamflow normality. The analyses of precipitation normality used the Direct Antecedent Rainfall Evaluation Method (DAREM) (Sumner et al. 2009), which determines if ground water monitoring occurred following a normal, above normal, or below normal precipitation period based upon long-term (i.e., 30 year) meteorological records (Sprecher and Warne 2000; Berkowitz and Noble 2015). The DAREM approach evaluates precipitation patterns during and three months prior to each saturation event, weighting more recent precipitation to accurately reflect 
Fig. 3 Analyses of water table levels, precipitation, and river stage were used to categorize saturation events derived from (a) precipitation, (b) flooding, or (c) a combination of precipitation followed by subsequent flooding. Some study locations exhibited (d) a precipitation induced saturation event followed by a period of low water table and a separate event(s) occurring later in the season
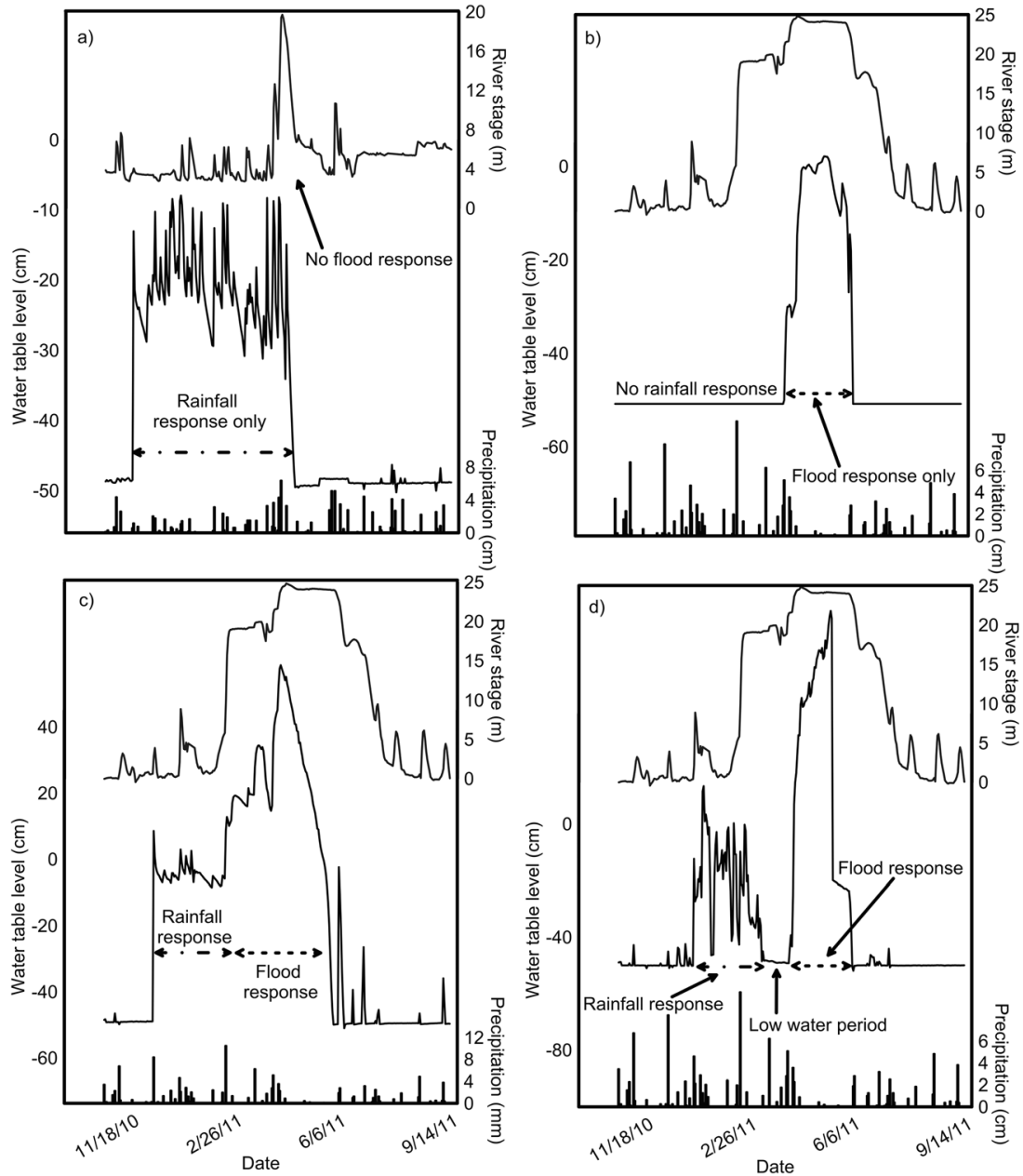

antecedent soil moisture levels. Monthly normal precipitation ranges were defined using the 30th and 70th percentile levels according to the Climate Analysis for Wetlands Tables (i.e., WETS; Sumner et al. 2009). The DAREM method has been utilized in numerous studies and is recommended for interpreting wetland hydrology data (USACE 2005; National Technical Committee for Hydric Soils 2015). The weather stations utilized for precipitation analyses included Clarksdale, MS (cooperative identification number 221707); Stoneville EXP STN, MS (228445); and Yazoo City 5 NNE, MS (229860).

Analyses of surface water levels examined cumulative discharge compared with 25 th and 75 th percentile flows at longterm ( $>30$ year) gauge stations. This approach is commonly used to determine streamflow normality (Gore and Banning 2017). Stream flow data were retrieved from the Bogue Phalia NR at Leland, MS (USGS gauge station 07288650); and the Big Sunflower River at Clarksdale, MS (07288000), Anguilla, MS (07288700), and Holly Bluff, MS (maintained by the US Army Corps of Engineers, Vicksburg District). Station selection was based upon proximity to study locations and longterm (i.e., >30 year) data availability.

\section{Long-Term Monitoring Data}

In order to examine a longer-term record, 12 wetland monitoring locations were maintained for three to eight years during the 2011-2018 period. Monitoring locations were located in the southern portion of the Yazoo Basin within the Delta National Forest and the adjacent Twin Oaks Wildlife Management Area. All study locations were characterized by mature second growth forested wetlands distributed across several mapped flood frequency return (i.e., 2-5 years) and duration $(<7->14$ day) zones. The flood duration and frequency zones were determined using the Flood Event Simulation Model (FESM), a flood mapping tool that interpolates water surface elevations between river gauges using a 2$\mathrm{m}$ digital elevation model. The model assumes that areas with surface elevations lower than the calculated water surface elevation are subject to surface inundation.

The duration of high water table (i.e. days with soil saturation $\leq 30 \mathrm{~cm}$ of the soil surface) was calculated annually and monthly using the Proc Univariate (SAS release 9.4, SAS Institute) analysis program. Similarly, the sum of the days the river surface water elevation exceeded the 2-year flood 
frequency elevation was calculated at Anguilla, MS and Holly Bluff, MS gauge stations as described above. Net precipitation was also calculated by subtracting monthly evaporation from precipitation using data from Rolling Fork, MS (227560) the only station in the southern portion of the Yazoo Basin that reports evaporation.

\section{Results and Discussion}

\section{Saturation Events - Water Source, Timing and Duration}

Ninety-five saturation events, defined as $\geq 14$ consecutive days of inundation (i.e., flooding or ponding) or soil saturation within the upper $30 \mathrm{~cm}$ of the surface, occurred at the 56 study locations during the 2010-2011 monitoring period (Table 1; USACE 2005). Twenty-five study locations exhibited one saturation event, 23 locations exhibited two events, and 8 locations exhibited three events (Supplemental Figs. 1-56). The duration of saturation events ranged from as few as 14 days to as many as 165 days (mean \pm standard error $=50.8 \pm 4.1$ days). Precipitation induced the majority of saturation events (75.7\%; 72 of 95 events). Flooding provided the hydrologic source for $18(18.9 \%)$ of the saturation events. Five saturation events $(5.2 \%)$ displayed initial soil saturation in response to precipitation, with supplemental flood inputs occurring after the minimum period of 14 consecutive days of saturation was surpassed. Results suggest that precipitation provides the dominant water source for most saturation events, with flooding providing the main water source at some locations and extending the duration of wetland saturation in other locations.

The timing and duration of saturation events differed with hydrologic source. Precipitation-driven events began in November and continued until April, with most events (65 of 72) occurring between January and April (Fig. 4). Flood derived saturation events were observed later in the growing season, from March to June. The distribution of events suggests that precipitation provides the water source to wetlands during the early portion of the water year, with flooding extending or supplementing saturation in some wetlands into the late spring and early summer months. This pattern follows established forested wetland hydrographs theorized by Mitsch and Gosselink (2015; Fig. 1) and reported in other studies (Kleiss et al. 2000). The duration of wetland saturation events associated with precipitation ( $44 \pm 4$ days) and flood (41 \pm 5 days) derived events did not significantly differ $\left(\mathrm{P}^{\prime}=\right.$ $0.88)$. However, the duration of events driven by a combination of precipitation and flooding (135 \pm 20 days) were significantly longer than events related to a single source of either precipitation $\left(\mathrm{P}^{\prime} \leq 0.001\right)$ or flooding $\left(\mathrm{P}^{\prime}=0.006\right)$.

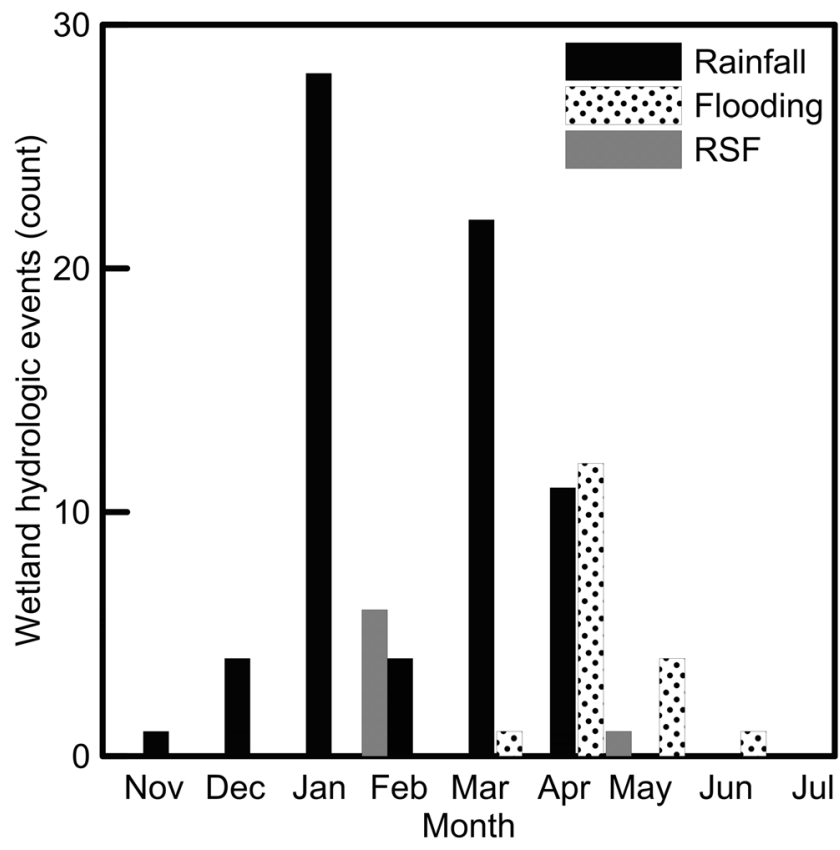

Fig. 4 Distribution of saturation event timing and water source during the study period. Note that most precipitation-driven events began during the winter, while flood derived events occurred during spring and summer. $\mathrm{RSF}=$ rainfall followed by supplemental flooding

Surface inundation patterns play an important role in many forested wetland functions, including habitat suitability for hydrophytic flora (i.e., Lindera melissifolia) and fauna (i.e., fish) and ecosystem productivity (Kozlowski 2002). The extent and duration of surface inundation differed between hydrologic sources. Thirty two of the 72 observed precipitationdriven events $(44 \%)$ included one or more days with water tables above the soil surface, thus the majority of precipitation-driven events $(56 \%)$ resulted from soil saturation without surface inundation. Where surface inundation did occur during precipitation induced events, the mean duration of surface inundation was 6.8 days (range $=1-32$ days) and the maximum depth of inundation ranged from 2 to $74 \mathrm{~cm}$ $($ mean $=9.7 \mathrm{~cm})$.

Flood-driven saturation events were all associated with surface inundation, displaying a significantly longer mean inundation duration of 27.5 days (range $=2-74$ days; $\mathrm{P}^{\prime}<0.001$ ) than precipitation-driven events. Flood derived events also exhibited significantly deeper maximum inundation depths $($ mean $=$ $\left.43.7 \mathrm{~cm} ; \mathrm{P}^{\prime}=0.002\right)$ than precipitation-driven events. Saturation events affected by precipitation followed by supplemental flooding also experienced significantly longer surface inundation than events driven by precipitation only (mean = 94.1 days; range $=3-134$ days; $\mathrm{P}^{\prime}=0.001$ ) but did not significantly differ from events induced by flooding $\left(\mathrm{P}^{\prime}=0.527\right)$. Maximum observed inundation depths during events induced by a combination of precipitation and flooding were also significantly deeper $($ mean $=45 \mathrm{~cm}$; range $=18-64 \mathrm{~cm})$ than events resulting from precipitation only $\left(\mathrm{P}^{\prime}<0.001\right)$. 
The observed distribution of hydrologic drivers, timing, and duration of saturation events likely reflect the large-scale alterations across the Yazoo Basin and more broadly within the lower Mississippi River Valley. Historically, prolonged and extensive ponding occurred in the Yazoo Basin following precipitation during the winter wet season (Smith and Klimas 2002). Localized flooding occurred as precipitation and runoff from the surrounding landscape (mostly the hills on the eastern edge of the basin) discharged into the tributary network of the Yazoo River, which provides the only natural drainage feature to the Mississippi River at the southern end of the basin (Fig. 2). Additionally, large flood events associated with the Mississippi River and tributary system inundated most of the Yazoo Basin in some years (Moore 1972). The modern levee system limits overbank flooding from the Mississippi River, but does not eliminate the influence of the river on wetland hydrology within the basin. For example, the major flood of 1973 inundated approximately 40\% of the Yazoo Basin; and subsequent analysis indicated that in the absence of the levee system nearly the entire basin would have become flooded (USACE 1973; Chin et al. 1975). While the implementation of flood control measures has decreased flood frequency and duration in portions of the Yazoo Basin (Smith and Klimas 2002), development of the Mississippi River levee system in conjunction with incomplete flood control projects in the southern portion of the Yazoo Basin increased the duration of saturation in some wetlands during some years (Stanturf et al. 2001). There was no significant difference between the average hydroperiods in the southern portion of the study area (107 \pm 6 days; $n=44)$ and the northern section of the Yazoo Basin ( $82 \pm 11$ days; $n=12)\left(\mathrm{P}^{\prime}=0.142\right)$.

\section{Monitoring Location Results}

Classification of each monitoring location by dominant water source promotes a discussion of the capacity of wetlands to persist under various river discharge and precipitation conditions, which respond to changes in land management and climate (Zhang and Schilling 2006; Jha et al. 2004). Precipitation provided the main water source at 38 of the 56 study locations (67.9\%) examined (Table 1). These locations exhibited no influence of flood inputs during the study (i.e., no saturation events linked with flooding occurred). Additionally, $19.6 \%$ of locations received sufficient precipitation to induce wetland hydrology, with subsequent flooding either 1) supplementing precipitation-driven hydrology (10.7\%) during a continuous event (Fig. 3c) or 2) leading to a separate wetland saturation event $(8.9 \%)$ following a period when water tables decreased below $30 \mathrm{~cm}$ for some period (Fig. $3 \mathrm{~d}$ ). These data suggest that $87.5 \%$ of monitoring locations would continue to exhibit saturation (and wetland hydrology) in the absence of flood inputs. Conversely, flooding provided the dominant water source at seven $(12.5 \%)$ of the 56 monitoring locations, supplemented precipitation induced saturation at five (8.9\%) locations, and led to a separate saturation event at six (10.7\%) locations. This suggests that flooding supported wetland hydrology at $32.1 \%$ of monitoring locations, and those locations would theoretically continue to exhibit wetland characteristics in the absence of precipitation inputs. However, it should be noted that the interactions of direct precipitation, runoff, and flooding are closely coupled; and isolating flood effects remains difficult without conducting a comprehensive mass balance of water budgets (Kolka et al. 2000).

The duration of saturation at study locations also differed across dominant water sources. For example, study locations in which flooding provided the dominant water source exhibited significantly shorter hydroperiods ( $42 \pm 4$ days) than all other categories $(P<0.001)$. Study locations with precipitation-driven saturation experienced $103 \pm 6$ days of elevated water tables, similar to data from locations with separate precipitation and flood events ( $122 \pm 18$ days; $P=0.526)$ but significantly less than locations with one continuous saturation period associated with precipitation supplemented with flood inputs $(154 \pm 6$ days; $P=0.009)$. Wetland hydroperiods in sites exposed to a combination of precipitation and flooding did not significantly differ $(P=0.381)$ despite the fact that some locations exhibited a continuous saturation event while others experienced a low water period separating the precipitation and flood induced saturation events (Table 1; Fig. 3c, d).

Surface inundation occurred at 42 of the 56 study locations (75\%), including all study locations subject to flood influences. The length of inundation varied across flood effected sites, ranging from 2 to 134 days $(47 \pm 8.5)$. Precipitation induced surface inundation at 24 of the $38(63 \%)$ monitored wetlands where flood inputs were absent, although the duration of inundation was often short $(5.0 \pm 1.7$ days). The remaining precipitation-driven locations displayed high water tables and soil saturation without surface water inundation. As noted elsewhere, the absence of flood inputs and associated decreases in surface inundation may reflect hydrologic alteration within the study area and represent an increase in wetlands subject to soil saturation compared with historic conditions. The potential decrease in surface inundation has implications for wetland functional capacity and management (discussed below).

Mapped flood duration and frequency data were available from the FESM model at 37 of the 56 study locations. The FESM results indicate the estimated frequency (e.g., 2-year flood return zone; 2-year floodplain) and duration (e.g., 28day of flooding) of flood inundation events based on surface elevation and river stage. Notably, the observed period of sol saturation exceeded the mapped flood duration in all cases. The measured duration of saturation generally increased with increases in mapped flood duration. For example, monitoring locations within the 28-day mapped flood 
duration zone exhibited significantly longer hydroperiods ( $160 \pm 2$ days) than locations in the $<7$-day mapped flood duration zone $\left(80 \pm 10\right.$ days; $\left.\mathrm{P}^{\prime} \leq 0.001\right)$ or locations in unmapped areas ( $90 \pm 8$ days; $\mathrm{P}^{\prime}=0.003$ ) (Table 2$)$. No statistically significant differences the period of soil saturation were detected across mapped flood frequency zones.

The available data suggests that the flood duration and frequency mapping may not accurately reflect ground conditions in regard to wetland hydropatterns, especially in locations subject to precipitation induced saturation. Within the study area, supplemental wetland mapping efforts may be required to document the extent of wetlands sustained by precipitation and soil saturation in addition to those subject to flooding. Further, the terms "saturation duration" and "saturation frequency" may more appropriately communicate wetland hydropatterns than traditional "flood frequency" and "flood duration" descriptions, since many of the saturation events and monitoring locations were subject to precipitation induced wetland hydrology.

Previous studies evaluated the impact of land use on forested wetland hydrology, reporting significant differences between natural and restored wetland forests (Kolka et al. 2000; Hunter et al. 2008). Restored wetlands and mature second growth forests in the current dataset displayed a variety of hydrologic sources (Table 1). Precipitation dominated hydrologic sources under both conditions, accounting for $77.3 \%$ and $73.8 \%$ of saturation events in restored and second growth forests respectively. Flooding drove wetland hydrology at $15.0 \%$ of the restored study locations, fewer than the $23.8 \%$ observed in second growth areas. The combination of initial precipitation inputs with subsequent supplemental flooding resulted in saturation events at $7.5 \%$ in restored areas and $2.4 \%$ in mature forest locations. There was no significant difference between mean hydroperiod in restored wetlands ( $99 \pm 8$ days) and second growth sites $(108 \pm 8$ days $)(P=0.176)$.

\section{Climate Analyses}

Analyses of rainfall and river discharge normality is required to place these results in a larger climatic context, as antecedent groundwater levels influence the impact of local rainfall and flooding on wetland saturation. For example, precipitation is more likely to result in near-surface saturation when groundwater tables are already elevated. The DAREM analyses indicated that each 2010-2011 saturation event occurred during a normal or drier than normal rainfall period (Supplemental Tables 1-36). This precludes the possibility that the predominance of precipitation-driven saturation events and study locations resulted from higher than normal rainfall. The 2010-2011 study period saw record discharges on the Mississippi River $\left(>56,000 \mathrm{~m}^{3} / \mathrm{s}\right)$ with stages exceeding the highest level on record, set during the historic flood of 1927 (Camillo 2012). Within the Yazoo basin a distinct flood effect can be observed during May and June (Fig. 3b). However, cumulative discharges displayed periods of below average stream flows within the study area during the 2010-2011 period, with portions of the study exhibiting discharges near the 25th percentile (Fig. 5a).

In response, analyses of available data from a higher than normal discharge year was examined to investigate the response of wetlands to above average river discharge and determine whether the relative influences of precipitation and flooding on saturation observed in the 2010-2011 dataset would persist. The 2015-2016 period was selected for evaluation because discharges remained near or above the 75th percentile level, and 10 wetland monitoring locations in the
Table 2 Mean wetland hydrology data ( \pm one standard error) across flood mapped flood duration, frequency, and water sources. N/A = no duration and frequency mapping data available; $\mathrm{R}=$ rainfall $; \mathrm{F}=$ flooding; RSF = rainfall followed by supplemental flooding

\begin{tabular}{|c|c|c|c|c|c|}
\hline \multirow[t]{2}{*}{ Flood duration (days) } & \multirow[t]{2}{*}{ Study locations (count) } & \multirow[t]{2}{*}{$\begin{array}{l}\text { Saturation period } \\
\quad \text { (days with water table } \leq 30 \mathrm{~cm} \text { ) }\end{array}$} & \multicolumn{3}{|c|}{$\begin{array}{l}\text { Water source } \\
\quad \text { (count) }\end{array}$} \\
\hline & & & $\mathrm{R}$ & $\mathrm{F}$ & RSF \\
\hline$<7$ & 12 & $82 \pm 10$ & 3 & 3 & 1 \\
\hline 7 & 17 & $109 \pm 11$ & 11 & 6 & 2 \\
\hline 14 & 1 & 109 & 1 & 1 & \\
\hline 21 & 1 & 120 & 1 & & \\
\hline 28 & 6 & $160 \pm 2$ & 2 & & 4 \\
\hline N/A & 19 & $90 \pm 8$ & 19 & 1 & \\
\hline Flood frequency (years) & Study locations & Saturation period & $\mathrm{R}$ & $\mathrm{F}$ & RSF \\
\hline 1.11 & 1 & 109 & 1 & 1 & \\
\hline 1.25 & 8 & $139 \pm 16$ & 3 & 1 & 4 \\
\hline 1.5 & 18 & $113 \pm 9$ & 13 & 5 & 2 \\
\hline 2 & 2 & $90 \pm 34$ & 1 & 1 & \\
\hline 5 & 6 & $77 \pm 13$ & 5 & 2 & \\
\hline 10 & 2 & $69 \pm 40$ & 1 & 1 & \\
\hline N/A & 19 & $90 \pm 8$ & 19 & 1 & \\
\hline
\end{tabular}


Fig. 5 Cumulative discharge curves for the (a) 2010-2011 and (b) 2015-2016 monitoring periods. Note that during 2010 2011, discharges remained below average often near the 25 th percentile level while in 2015-2016 discharges were near or above the 75th percentile level. During both time periods, precipitation inputs induced most wetland saturation events and was the dominant water source at most study locations. Data presented from the Big Sunflower River gauge at Holly Bluff, MS.

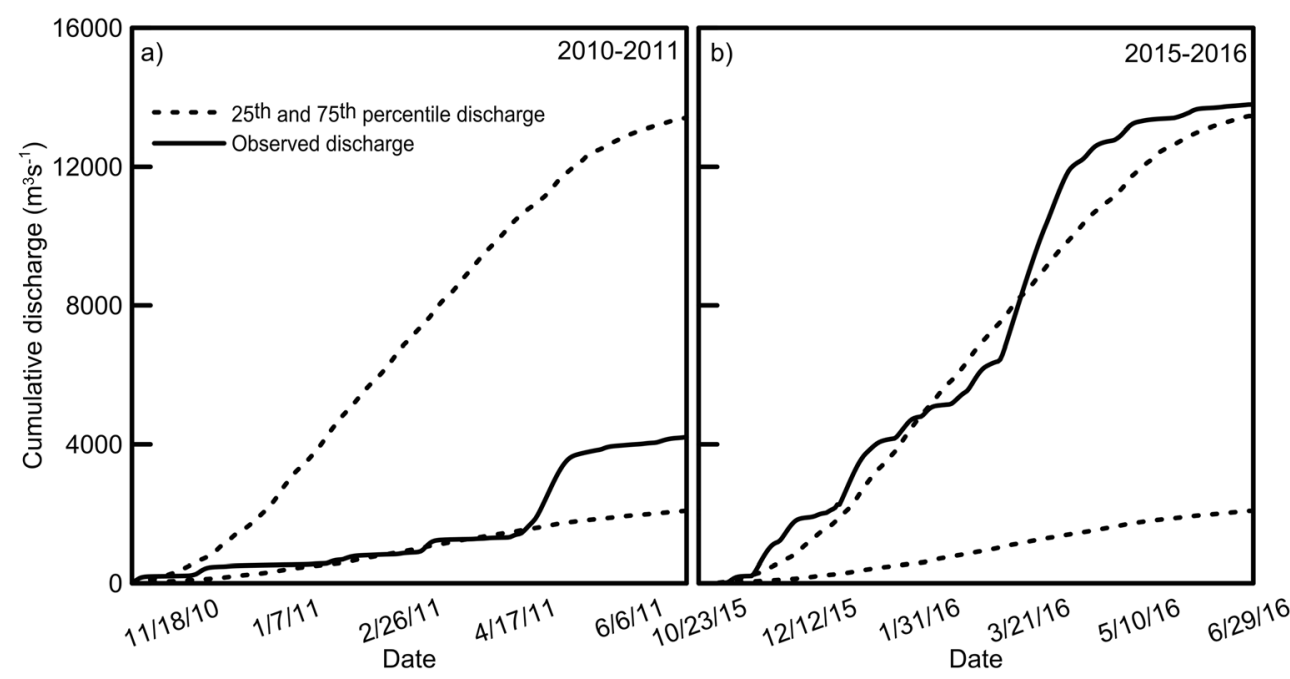

study area were still in operation (Fig. 5b). Precipitation ranged from normal ( 7 months) to wet ( 5 months) and 17 saturation events occurred during 2015-2016 monitoring period (Supplemental Tables 37-48).

As seen in the larger 2010-2011 dataset, the majority of saturation events recorded during 2015-2016 were associated with precipitation $(70.5 \%)$. Fewer events were induced by flooding (29.5\%), including three of the 17 events which displayed initial precipitation responses followed by supplemental flood inputs. Analyses of individual study sites also followed the trend seen in the 2011-2010 data. Nine of the 10 study locations included at least one precipitation-driven saturation event, with precipitation providing the main water source at seven locations. Flooding occurred at the remaining three locations providing: the main water source at one study location, supplemental hydrology to an ongoing precipitation-driven event at one location, and separate precipitation and flooding events at one location. Results from a higher than normal discharge period appear to agree with the 2010-2011 data, with precipitation supporting most saturation events and study locations and flooding providing the dominant or supplemental water source at a subset of locations.

\section{Long-Term Hydrologic Monitoring}

Twelve long-term monitoring locations were maintained for three to eight years in order to evaluate trends across multiple years (Table 3 ). The long-term monitoring locations included a variety of mapped flood duration ( $<7$ to $>14$ days) and frequency ( 2 to 5 year) zones. As anticipated, study locations in higher mapped flood frequency and duration zones generally exhibited longer hydroperiods. For example, monitoring locations in the 2-year flood frequency zone displayed fewer days of soil inundation/saturation as mapped flood duration decreased as follows: >14-day duration (average observed hydroperiod \pm one standard error $=172 \pm 20$ days); 7-14 day duration ( $151 \pm 16$ days); <7-day duration ( $87 \pm 16$ days). Note that the observed duration of soil inundation or saturation greatly exceed the mapped flood duration across each flood frequency and duration zone, further suggesting that precipitation is driving wetland hydrology. These long-term water table monitoring results support the conclusion outlined above, that precipitation provides the dominant wetland hydrologic force within the study area.

To illustrate the long-term hydropatterns, the average soil period of monthly saturation was plotted in a time series along with the net monthly precipitation (i.e., precipitation minus evapotranspiration) and the period when river stages were elevated. First, data from the mapped 2-year frequency, $>14-$ day duration flood zone (Fig. 6a) highlights the fact that the period of precipitation-driven saturation always exceeds the period of flooding, and that saturation was observed during all years, regardless of timing or extent of flooding. Examining 2year flood frequency, 7-day duration flood zone further emphasizes the role of precipitation (Fig. 6b). A single 2-year flood event occurred during the monitoring period (March 2016) following a precipitation event in which the upstream basin received more than $500 \mathrm{~mm}$ of rain over a 48-h period. As a result, all of the observed soil saturation except during March 2016 event can be attributed to precipitation. Evaluating long-term water tables in the 5-year frequency, <7-day duration flood zone also supports the dominant role of precipitation in wetland hydrology. There were no flood events exceeding the 5-year frequency during the period of study, thus all of the observed soil saturation in this flood frequency and duration zone are attributed to precipitation.

\section{Management and Restoration Implications}

Wetlands within the Mississippi River Valley have been shown to provide a number of wetland functions related to 
Table 3 Long-term water table monitoring results from 12 wetland locations. Data includes mapped flood frequency, duration, and the observed annual period of inundation or saturation within $\leq 30 \mathrm{~cm}$ of the soil surface. Note that wetland hydrology was observed at all sites at $>50 \%$ frequency and the period of high water table surpassed the mapped flood duration regardless of interval. This suggests that precipitation is providing the dominant water source in the forested wetlands evaluated

\begin{tabular}{|c|c|c|c|c|c|c|c|c|c|c|c|}
\hline \multirow{2}{*}{$\begin{array}{l}\text { Sample } \\
\text { Location }\end{array}$} & \multirow{2}{*}{$\begin{array}{l}\text { Mapped flood } \\
\text { frequency } \\
\text { (years) }\end{array}$} & \multirow{2}{*}{$\begin{array}{l}\text { Mapped flood } \\
\text { duration } \\
\text { (days) }\end{array}$} & \multicolumn{8}{|c|}{ Annual period of observed soil saturation or inundation (days) } & \multirow{2}{*}{$\begin{array}{l}\text { Average hydroperioc } \\
\text { (days) }\end{array}$} \\
\hline & & & 2011 & 2012 & 2013 & 2014 & 2015 & 2016 & 2017 & 2018 & \\
\hline $\mathrm{N}$ & 2 & $>14$ & 159 & 192 & 238 & 179 & & & & & 192 \\
\hline $\mathrm{P}$ & 2 & $>14$ & 132 & 141 & 155 & 164 & 194 & 125 & & & 152 \\
\hline $\mathrm{S}$ & 2 & $7-14$ & 156 & 152 & 167 & & & & & & 158 \\
\hline $\mathrm{L}$ & 2 & $7-14$ & 41 & 133 & 128 & 153 & 179 & 136 & & & 128 \\
\hline $\mathrm{H}$ & 2 & $7-14$ & 160 & 182 & 231 & 221 & 226 & 157 & 180 & & 194 \\
\hline $\mathrm{J}$ & 2 & $7-14$ & 81 & 136 & 150 & 123 & & & & & 123 \\
\hline $\mathrm{R}$ & 2 & $<7$ & 94 & 90 & 165 & 120 & 126 & 127 & 89 & 101 & 114 \\
\hline $\mathrm{U}$ & 2 & $<7$ & 60 & 25 & 76 & 23 & 78 & 81 & & & 57 \\
\hline $\mathrm{D}$ & 2 & $<7$ & 6 & 26 & 158 & 89 & 144 & 124 & & & 91 \\
\hline $\mathrm{Y}$ & 5 & $<7$ & 109 & 138 & 132 & 37 & 203 & 123 & & & 124 \\
\hline B & 5 & $<7$ & 6 & 10 & 126 & 69 & 136 & 107 & & & 76 \\
\hline A & 5 & $<7$ & 0 & 0 & 126 & 51 & 109 & 97 & & & 64 \\
\hline
\end{tabular}

hydrology, habitat, and biogeochemical cycling, which subsequently support ecological services that benefit society (e.g., flood risk reduction, subsistence harvesting, water quality; Novitski et al. 1996; Thorp et al. 2010). Within forested wetlands in the Yazoo Basin Smith and Klimas (2002) identify seven wetland functions including detention of 1) floodwaters and 2) precipitation, 3) nutrient cycling, 4) organic carbon export, 5) sequestration of elements and compounds, 6) maintenance of plant communities, and 7) support for fish and wildlife habitat. Previous studies in the basin evaluated these functions across a variety of landscape conditions, demonstrating that wetland functions generally increase with wetland forest successional age and that restored wetlands provide the same functions as natural systems but often at a lower magnitude (Berkowitz and White 2013; Berkowitz 2019).

The ability of a wetland to provide ecosystem functions depends on many conditions related to landscape position, hydrodynamics, successional stage, and other factors (Smith et al. 1995; USGS 1996). For example, the detain floodwater function is maximized in areas that are exposed to frequent flooding, contain sufficient surface roughness (i.e., obstructions and microtopography) to decrease the flow velocities, and have sufficient storage capacity to detain surface water inputs (Ritter et al. 1995). The data presented here suggests that precipitation drives the hydrology of many of the wetlands in the study area, which likely experience less flooding than under an unaltered hydrologic regime (i.e., prior to agricultural conversion and/or levee construction). As a result, some wetlands in the Yazoo Basin may provide limited detention of floodwaters compared with historical conditions.
However, wetlands throughout the region are known to detain significant amounts of precipitation, which maintains saturation in many areas independent of the influence of flooding (Smith and Klimas 2002). Direct precipitation and runoff from surrounding areas accumulates on flats and in depressional features (both macro- and micro-scale) for storage as surface ponding and subsurface soil saturation. The water is removed from the system via evapotranspiration, groundwater recharge, and drainage into natural features or constructed ditches (Sun et al. 2002). The detention of precipitation in forested wetlands has the capacity to alter the timing, extent, and magnitude of downstream flooding within watersheds, even in systems not directly influenced by flooding (Acreman and Holden 2013). For example, mature forested wetland evapotranspiration has been shown to remove as much as $75 \%$ of precipitation inputs, reducing the volume of water contributing to potential downstream flood events (Sun et al. 2000). As a result, the precipitation supported wetlands of the Yazoo Basin provide indirect flood risk reduction

Fig. 6 Long-term average monthly duration of soil saturation within $\leq 30 \mathrm{~cm}$ of the soil surface (solid line) and elevated river stage (shaded area) across three mapped flood frequency and duration zones including study locations within the (a) 2-year frequency, 14-day duration flood zone (stage data from the Anguilla gauge); (b) 2-year frequency, 7-day duration flood zone (stage data from the Holly Bluff gauge); and (c) 5year frequency, 7-day duration flood zone (no flooding observed during the monitoring period). Note that the period of soil saturation exceeds the period of elevated river stage in all cases, indicating that precipitation is a major wetland water source in the study area. Net precipitation is also displayed, highlighting the relationship between observed wetland hydropatterns and the seasonal water balance (broken line) 

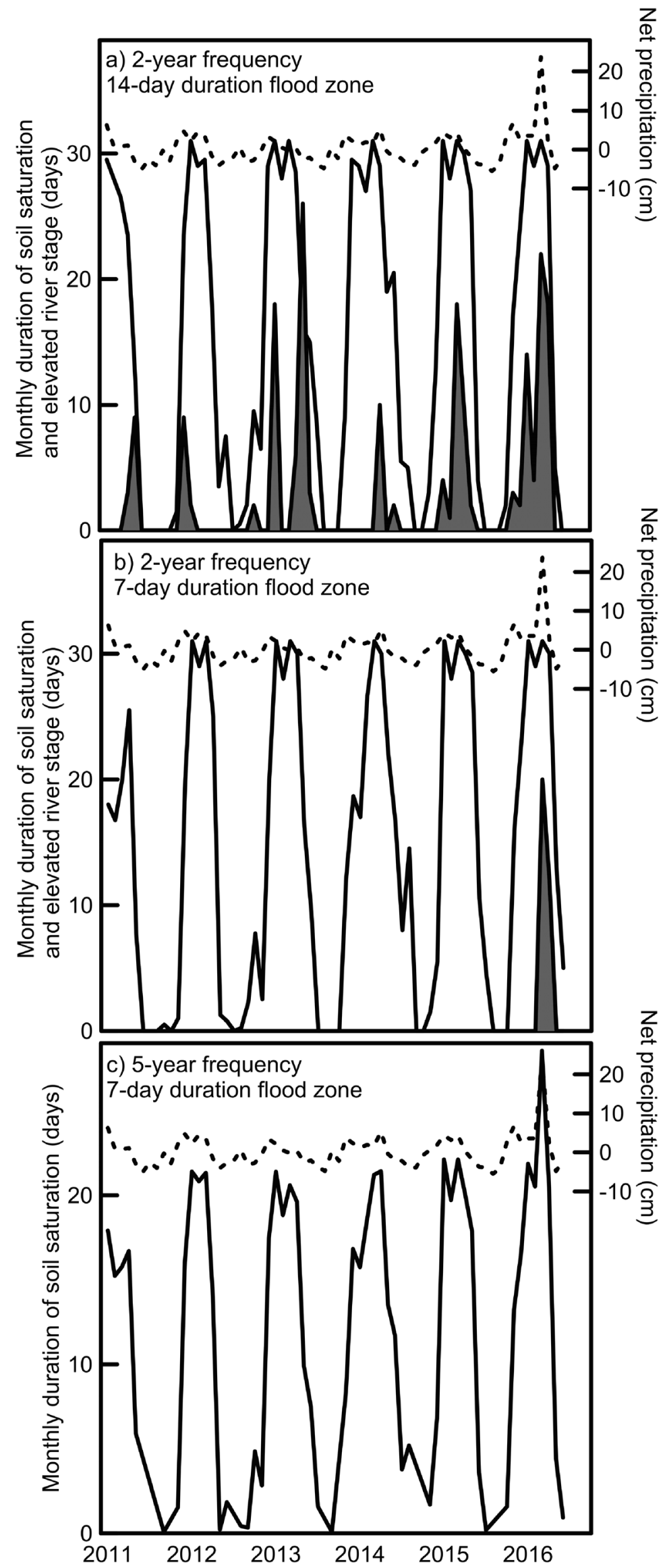
benefits through runoff attenuation even in the absence of floodwater inundation. Similarly, wetlands whose hydrology is predominantly derived from flooding continue to provide the detain precipitation function during low water periods. Wetlands across the Yazoo Basin (including measurements taken at a subset of those examined herein) have also been shown to provide biogeochemical cycling (e.g., nutrient and chemical transformations) and habitat functions to various degrees regardless of water source (Berkowitz 2019).

Understanding the primary drivers of saturation allows natural resource managers and entities pursuing forested wetland restoration to maximize wetland functions and ecosystem services based upon site conditions (Berkowitz and White 2013). For example, Kusler (2012) highlights the ability to maximize flood storage and conveyance features of wetland systems through hydrologic analysis and the manipulation of project site topography. As a result, wetlands that currently experience frequent flood events should be targeted for restoration or enhancement if project objectives include floodwater storage. Alternatively, wetlands currently disconnected from flooding can be reconnected or altered to maximize onsite precipitation storage, both of which reduce downstream flood risk across regional scales. In some cases, flood and precipitation-driven wetlands can work in concert to improve water quality. Forested wetlands inundated during flood events remove sediments and pollutants from surface waters. However, precipitation-driven wetlands have also proven effective for trapping sediments, nutrients, and other compounds prior to runoff entering surface waters (Johnston et al. 1984; Cooper et al. 1987); thus similar water quality benefits are being provided under both hydrologic regimes, although the magnitude and timing of the effect may differ.

The management of both precipitation and flood-driven forested wetlands can be focused to improve habitat for individual species or groups of species based upon the hydropatterns described above. For example, some species utilizing forested wetlands may prefer the saturated soils or shallow stagnant waters that persist for an average $103 \pm$ 6 days in many precipitation-driven wetlands to deeper wetlands with shorter hydroperiods ( $42 \pm 6$ days) associated with flooding, at least during portions of the year. These species likely include some migratory waterfowl and species that thrive in the absence of predation by river fishes; and these animals may utilize flooded wetland systems for dispersal or conveyance during other portions of their life cycle (e.g., salamanders; Allen 1980; Semlitsch 1988). Precipitation supported forested wetlands may also provide forested corridors connecting lotic systems within the agricultural landscape occupying much of the Mississippi River Valley region, and continuing efforts to restore tracts linking large wetland areas have been recommended to further enhance habitat functions across broad spatial scales (Schweitzer and Stanturf 1997).
In summary, forested wetlands within the Yazoo Basin are maintained by a combination of precipitation and flood water inputs. Precipitation provides the proximate water source for the majority of wetlands evaluated herein, supporting up to $87 \%$ of study locations. Flood induced wetland hydrology has likely declined in extent and duration, yet flooding sustained some wetlands and enhanced hydroperiods in sites experiencing both precipitation and flooding effects. The timing and duration of saturation differed with water source, highlighting the heterogeneity of wetland conditions within the Mississippi River tributary system. Future studies are needed to quantify the spatial extent of wetlands in the study area in terms of water source, because while large scale forested wetland restoration efforts have been implemented, historic alterations associated with land conversion and flood control have altered natural flood regimes. As a result, natural resource managers in the Yazoo Basin, and the Mississippi River Basin more broadly, should consider current water sources and hydropatterns within forested wetlands in order to target wetland functions for maximal ecological and societal benefits.

Acknowledgements The authors thank Kent Parrish, Gary Young, Patricia Tolley, Mark Farr, Brian Durham, and several anonymous reviewers for providing comments on the manuscript. Funding for the study was provided by the US Army Corps of Engineers Vicksburg District.

Open Access This article is distributed under the terms of the Creative Commons Attribution 4.0 International License (http:// creativecommons.org/licenses/by/4.0/), which permits unrestricted use, distribution, and reproduction in any medium, provided you give appropriate credit to the original author(s) and the source, provide a link to the Creative Commons license, and indicate if changes were made.

\section{References}

Acreman M, Holden J (2013) How wetlands affect floods. Wetlands 33(5):773-786

Allen CE (1980) Feeding habits of ducks in a green-tree reservoir in eastern Texas. J Wildl Manag 44(1):232-236

Belt CB (1975) The 1973 flood and man's constriction of the Mississippi River. Science 189(4204):681-684

Berkowitz JF (2019) Quantifying functional increases across a large-scale wetland restoration Chronosequence. Wetlands 39(3):559-573

Berkowitz JF, Noble CV (2015) Development of new hydric soil field indicators: guidelines for data collection and submission. Soil Horizons 56(1)

Berkowitz JF, Sallee JB (2011) Investigating problematic hydric soils using water table measurements, IRIS tubes, soil chemistry, and application of the hydric soils technical standard. Soil Sci Soc Am J 75(6):2379-2385

Berkowitz JF, White JR (2013) Linking wetland functional rapid assessment models with quantitative hydrological and biogeochemical measurements across a restoration chronosequence. Soil Sci Soc Am J 77:1442-1451

Berkowitz JF, Page S, Noble CV (2014) Potential disconnect between observations of hydrophytic vegetation, wetland hydrology indicators, and hydric soils in unique pitcher plant bog habitats of the 
southern Gulf Coast. Southeast Nat 13(4):721-734. https://doi.org/ $10.1656 / 058.013 .0410$

Berkowitz JF, Currie SJ, Pietroski JP (2017) Evaluation of wetland hydrology in formerly irrigated areas. Evaluation of wetland hydrology in formerly irrigated areas. ERDC/EL TR-17-13

Brown DA, Nash VE, Caldwell AG, Bartelli LJ, Carter RC, Carter OR (1971) A monograph of the soils of the southern Mississippi Valley alluvium. Arkansas, Mississippi, and Louisiana agricultural experiment stations in cooperation with the U.S. Department of Agriculture Soil Conservation Service. Southern Cooperative Series Bulletin 178

Camillo CA (2012) Divine providence: the 2011 flood in the Mississippi River and tributaries project. Mississippi River Commission, Vicksburg

Chin EH, Skelton J, Guy HP (1975) The 1973 Mississippi River basin flood: Compilation and analyses of meteorologic, flow, and sediment data. U.S. Geological Survey and National Oceanic and Atmospheric Association. Geological Survey Professional Paper 973

Cooper JR, Gilliam JW, Daniels RB, Robarge WP (1987) Riparian areas as filters for agricultural sediment 1. Soil Sci Soc Am J 51(2):416420

Davis MM, Sprecher SW, Wakeley JS, Best GR (1996) Environmental gradients and identification of wetlands in north-Central Florida. Wetlands 16:512-523

Fredrickson LH (2005) Contemporary bottomland hardwood systems: structure, function, and hydrologic condition resulting from two centuries of anthropogenic activities. In: Fredrickson LH, King SL, Kaminski RM (eds) Ecology and management of bottomland hardwood systems: the state of our understanding. University of Missouri-Columbia Press, Puxico

Fredrickson LH, Heitmeyer ME (1988) Waterfowl use of forested wetlands of the southern United States: an overview. Waterfowl in winter. University of Minnesota Press, Minneapolis, pp 307-323

Fredrickson LH, King SL, Kaminski RM (2005) Ecology and management of bottomland hardwood systems: the state of our understanding. University of Missouri-Columbia Press, Puxico

Gore JA, Banning J (2017) Discharge measurements and streamflow analysis. Methods Stream Ecol 1:49-70

Gosselink JG, Turner RE (1978) The role of hydrology in freshwater wetland ecosystems. In: Good RE, Whigham DH, Simpson RL (eds) Freshwater Wetlands: ecological processes and management potential. Academic Press, New York

Hunter RG, Faulkner SP, Gibson KA (2008) The importance of hydrology in restoration of bottomland hardwood wetland functions. Wetlands 28(3):605-615

Jha M, Pan Z, Takle ES, Gu R (2004) Impacts of climate change on streamflow in the upper Mississippi River basin: a regional climate model perspective. J Geophys Res Atmos 109(D9)

Johnston CA, Bubenzer GD, Lee GB, Madison FW, McHenry JR (1984) Nutrient trapping by sediment deposition in a seasonally flooded lakeside wetland 1. J Environ Qual 13(2):283-290

Kellison RC, Young MJ (1997) The bottomland hardwood forest of the southern United States. For Ecol Manag 90(2-3):101-115

King SL, Twedt DJ, Wilson RR (2006) The role of the wetland reserve program in conservation efforts in the Mississippi River Alluvial Valley. Wildl Soc Bull 34(4):914-920

Kleiss BA, Coupe RH, Gonthier GJ, Justus BJ (2000) Water quality in the Mississippi Embayment, Mississippi, Louisiana, Arkansas, Missouri, Tennessee, and Kentucky,1995-98: U.S. Geological Survey Circular 1208

Kolka RK, Singer JH, Coppock CR et al (2000) Influence of restoration and succession on bottomland hardwood hydrology. Ecol Eng 15: S131-S140

Kozlowski TT (2002) Physiological-ecological impacts of flooding on riparian forest ecosystems. Wetlands 22(3):550-561
Kusler JA (2012) Wetland creation and restoration: the status of the science. Island Press, Washington, DC

Matsuura K, Willmott C, Legates D (2009) WebWIMP version 1.02: the web-based, water-budget, interactive, modeling program. University of Delaware. http://climate.geog.udel.edu/ wimp/

Mitsch WJ, Gosselink JG (2015) Wetlands, 5th edn. John Wiley and Sons, Inc., Hoboken

Moore NR (1972) Improvement of the lower Mississippi River and tributaries 1931-1972. Mississippi River Commission, Vicksburg

National Oceanic and Atmospheric Administration (2019) National hydrologic assessment: March 21, 2019. National Weather Service, Office of Hydrologic Development

National Research Council (1995) Wetlands: characteristics and boundaries. National Academies Press. ERDC/EL TR-17-13

National Technical Committee for Hydric Soils (2015) Hydric soils technical note 11: hydric soils technical standard and data submission requirements for field indicators of hydric soils. USDA-NRCS, Beltsville

Novitski RP, Smith RD, Fretwell JD (1996) Wetland functions, values, and assessment. In: Fretwell JD, Williams JS, Redman PJ (eds) National water summary on wetland resources, vol 2425. USGS Water-Supply Paper, Washington, DC

Opperman JJ, Luster R, McKenney BA et al (2010) Ecologically functional floodplains: connectivity, flow regime, and scale 1. JAWRA J Am Water Resour Assoc 46(2):211-226

Richardson CJ, McCarthy EJ (1994) Effect of land development and forest management on hydrologic response in southeastern coastal wetlands: a review. Wetlands 14(1):56-71

Ritter DF, Kochel RC, Miller JR (1995) Process geomorphology, 3rd edn. William C. Brown Publishers, Chicago

Saucier RL (1994) Geomorphology and quaternary geologic history of the lower Mississippi Valley. Vol I (report), Vol II (map folio), U.S. Army Engineer Waterways Experiment Station, Vicksburg MS

Schweitzer CJ, Stanturf JA (1997) From okra to oak: reforestation of abandoned agricultural fields in the lower Mississippi Alluvial Valley. In: Proceedings of hardwood symposium May 7-10, 1997

Semlitsch RD (1988) Allotopic distribution of two salamanders: effects of fish predation and competitive interactions. Copeia 1988:290-298

Smith RD, Klimas CV (2002) A regional guidebook for applying the Hydrogeomorphic approach to assessing wetland functions of selected regional wetland subclasses, Yazoo Basin, lower Mississippi River Alluvial Valley. ERDC/EL TR-02-4. US Army Engineer Research and Development Center

Smith RD, Ammann A, Bartoldus C, Brinson MM (1995) An approach for assessing wetland functions using hydrogeomorphic classification, reference wetlands and functional indices. Technical Report TR-WRP-DE-9. Waterways Experiment Station, Army Corps of Engineers

Soil Survey Staff (2019) Natural resources conservation service, U.S. Department of Agriculture. Web Soil Survey. Available online at http://websoilsurvey.nrcs.usda.gov/. Accessed 4 Jan 19

Southern Regional Climate Center (1998) Electronic climate atlas. National Oceanic and Atmospheric Administration

Sparks RE, Nelson JC, Yin Y (1998) Naturalization of the flood regime in regulated rivers: the case of the upper Mississippi River. BioScience 48(9):706-720

Sprecher SW, Warne AG (2000) Accessing and using meteorological data to evaluate wetland hydrology. ERDC/EL TR-WRAP-00-1, U.S. Army Engineer Research and Development Center

Stanturf JA, Schoenholtz SH, Schweitzer CJ, Shepard JP (2001) Achieving restoration success: myths in bottomland hardwood forests. Restor Ecol 9(2):189-200

Sumner JP, Vepraskas MJ, Kolka RK (2009) Methods to evaluate normal rainfall for short-term wetland hydrology assessment. Wetlands 29(3):1049-1062 
Sun G, Lu J, Gartner D et al (2000) Water budgets of two forested watersheds in South Carolina. In: Higgins RW (ed) Proceedings of AWRA annual water resources conference. Water quantity and quality issues in the Coastal Urban Areas, Miami, pp 199-202

Sun G, McNulty SG, Amatya DM et al (2002) A comparison of the watershed hydrology of coastal forested wetlands and the mountainous uplands in the southern US. J Hydrol 263(1-4):92-104

The Nature Conservancy (1992) Restoration of the Mississippi River alluvial plain as a functional ecosystem. Southeastern Louisiana University, Hammond

Theiling CH, Nestler JM (2010) River stage response to alteration of upper Mississippi River channels, floodplains, and watersheds. Hydrobiologia 640(1):17-47

Thorp JH, Flotemersch JE, Delong MD et al (2010) Linking ecosystem services, rehabilitation, and river hydrogeomorphology. BioScience 60(1):67-74

U.S. Army Corps of Engineers (2010) Regional supplement to the corps of engineers Wetland delineation manual: Atlantic and Gulf coastal plain region (version 2.0).In: Wakeley JS, Lichvar RW, Noble CV (eds) ERDC/EL TR-10-20. U.S. Army Engineer Research and Development Center, Vicksburg, MS

U.S. Army Corps of Engineers (USACE) (1973) Mississippi River and tributaries post flood report: 1973. Lower Mississippi Valley Division, Vicksbug

U.S. Army Corps of Engineers (USACE) (2005) Technical standard for water-table monitoring of potential wetland sites. ERDC TN-
WRAP-05-02. Vicksburg, MS: U.S. Army Engineer Research and Development Center

U.S. Department of Agriculture, Natural Resources Conservation Service (USDA-NRCS) (2006) Land resource regions and major land resource areas of the United States, the Caribbean, and the Pacific Basin. U.S. Department of Agriculture Handbook 296

U.S. Department of Agriculture, Natural Resources Conservation Service (USDA-NRCS) (2018) Field indicators of hydric soils in the United States, Version 8.2. In: Vasilas LM, Hurt GW, Berkowitz JF (eds) USDA-NRCS, in cooperation with the National Technical Committee for Hydric Soils

U.S. Geological Survey (1996) National water survey of wetland resources. United States Geological Survey, Water-Supply Paper 2425

Walton R, Davis JE, Martin TH, Chapman RS (1996) Hydrology of the black swamp wetlands on the Cache River, Arkansas. Wetlands 16(3):279-287

Wigley TB, Roberts TH (1994) A review of wildlife changes in southern bottomland hardwoods due to forest management practices. Wetlands 14(1):41-48

Zhang YK, Schilling KE (2006) Increasing streamflow and baseflow in Mississippi River since the 1940s: effect of land use change. J Hydrol 324(1-4):412-422

Publisher's Note Springer Nature remains neutral with regard to jurisdictional claims in published maps and institutional affiliations. 